シンポジュウム：気管呼吸者の管理

$$
\begin{aligned}
& \text { 気管呼吸者の胸部レ線所見 } \\
& \text { *立入弘小竹武 } \\
& \text { 小塚隆弘野崎公敏 } \\
& \text { **村 井 知 也 } \\
& \text { ****町節 子 }
\end{aligned}
$$

\title{
Radiological Findings in Chest of Patients After Total Laryngectomy
}

\author{
H. Tachiiri, M.D., et al.
}

Prof. and Radiologist in Chief, Department of Radiology, Osaka University Hospital

Since 1949 we have been working on periodical examination for a large group of over 700 patients who underwent the total laryngectomy due to laryngeal cancer and have spoken by means of esophageal speech method or with a speech instrument.

It was planned with a purpose of following studies:

a) Estimation of general organic and functional conditions of such senile patients and guidance or controle of personal life.

b) Detection of local recurrence or metastases to other organs, especially to the lung, in early stage.

c) Influencet of inhalation through the stoma of the trachea on the lung.

d) Roentgenologic analysis of phonation and speech mechanism by means of cinematography.

e) Relation between abnormal speech methods and condtions of G-1-tract.

For b) and c) we have used all sorts of roentgen examination technics, such as plain and contrast, including high-voltage and direct magnification radiography, which make us possible to interprete various abnormalities of lung markings, especially of vascular shadows. Results obtained, concerning about b) and c) are as follows:

1) Recurrences or lung metastases of laryngeal cancer were chiefly concentratrated within 5 years after operation, particularly frequent in the first 2 years.

2) Primary lung cancer of any other organs, for example, stomach, intestine or kidney, were revealed in relative higher incidence.

3) Changes of bronchopulmonary system were found in various forms and grades:

(i) chronic and recurrent inflammation,

(ii) fibrotic changes, above all, of interstitial tissues, which leds to abnormalities of vascular shadow, such as irregular running course, unbalanced calibre and/or irregular contour, and

(iii) emphysema.

\footnotetext{
*大阪大学医学部放射線医学教室

**国立只病院

***西官市立中央病院
} 
私達のところでは，大阪大学耳鼻咽喉科関係 で喉頭全剔出を行なつた患者集団である阪喉会 （佐藤博士の項参照）会員約 750 名と他の僅か な人達を対象として1961から毎年少なくとも 1 回の健康診断を行なつて来ている。この集団は 非常に協力的ではあるが, 老齢の人も多く, 居 住地も随分と広、範囲にわたつてもおり, 全身 的に見れば他の疾患をもつていることもあつ て, 多数の会員を常に検診に動員することは不 可能である。従つて, 今までに健診に加つた人 数の総計は475名であるが, 毎回の受診者は 100 〜200名で，その中には毎回連続の人もあれば， 数回しか来ていない人もあり, 死亡その他で途 中で脱落したり, 手術後の年数が少なくて 1 回 しか検診の機会がなかつた人も算えられている

(第 1 表)。

第 1 表 受検者全員の年令と術後年数 （各個人の最終受検時の年令と経過年数）

\begin{tabular}{c|c|c|c|c|c|c|c|c}
\hline 年 & 令 & -40 & -50 & -60 & -70 & -8081 & 計 \\
年 \begin{tabular}{c} 
数 \\
\hline-1
\end{tabular} & & 4 & 26 & 30 & 4 & & 64 \\
\hline-2 & 1 & 6 & 19 & 31 & 7 & 1 & 65 \\
\hline-3 & 1 & 6 & 24 & 27 & 9 & & 67 \\
\hline-4 & & 1 & 6 & 16 & 9 & & 32 \\
\hline-5 & & 1 & 10 & 25 & 3 & & 39 \\
\hline-10 & 1 & 4 & 39 & 73 & 22 & 1 & 140 \\
\hline-15 & & 1 & 11 & 25 & 9 & 2 & 48 \\
\hline-20 & & & 2 & 4 & 7 & 1 & 15 \\
\hline $21-$ & & & & 1 & 1 & & 2 \\
\hline 不 詳 & & 1 & 1 & & 1 & & 3 \\
\hline 計 & 3 & 24 & 139 & 232 & 72 & 5 & 475 \\
\hline
\end{tabular}

\section{検診の目的と方法}

検診の目的は勿論, 癌の局所再発と転移の発 生の監視及びこれに直結する治療の問題が第 1 ではあるが, 正常の鼻腔あるいは口腔から咽喉 頭を経由する呼吸にくらべて, 全摘術後の気管 開口部から直接に気管への呼吸及びこれに伴う 異常発声法等が，気管支肺系へどのような変化 を及ぼすであろらか，そしてそれがあるとすれ
ばどのように対処すべきかを考慮するのも大切 なものとした。

故に検診方法としては：

1. 問, 視, 聴, 打, 触診などの一般的健康 診断

2. 胸部レ線検査：125 kVp の高圧撮影法を 以てする正側面 2 方向撮影, 必要に応じて 追加されるレ線直接拡大撮影及び断層撮 影，気管支造影と血管造影。

3. 呼吸機能測定 : 各種の肺活量。

4. 循環器検査: 心電図, 血圧。

5. 消化管レ線検查

を採つているが，その軸となるものは正・側面 の胸部レ線写真である。その観察と読影には常 に教室の胸部疾患グループと心血管グループの 1 人ずつが対となつた数組を作つて複数観察制 をとつて，主観に走ることを避けるとともに見 落し，見過ぎのないように努めた。

\section{胸部レ線写真上の検查項目}

1. 腫瘤状影（腫場の転移，原発）

2. 上部縦隔洞の変化 (局所再発その他)

3. 局在性融合影 (炎症, 無気肺)

4. 線・網状影 (間質性肺炎一線維性変化, 襄胞形成, 慢性気管支炎 気管支拡張)

5. 結節影（間質性肺炎～線維性変化, 慢性 気管支炎など)

6. 異常透明部 (肺気腫, 霓胞形成)

7. 肺紋理〜血管影の異常（間質性肺炎～線 維性変化, 微小気腫と微小無気肺など)

$$
\mathrm{a}: \text { 走行の異常 }
$$

$\mathrm{b}$ : 径の不整

$\mathrm{c}$ ：輪郭の不規則化

8. 肋膜の変化

9. 心 ・大血管の変化

10. 結核性病変 (結核性変化が気管直接呼吸 でどのように影響されるか)

\section{乼目すべきレ線像上の変化（表 $2 ， 3 ， 4$ ）}

1) 局所再発：腫廈が胸部の方一浸潤性に進ん で来ると, 上部縦隔洞に腫境浸潤陰影を示す。 しかし, これは正面レ線写真からだけでは動脈 硬化症の一部として見られる無名動脈系の届曲 (Buckling) と鑑別し難いことがある。喉頭癌か らの再発と転移は殆んど5 
る。

2）転移, 第二の癌(重複癌)：喉頭癌の肺転移 と原発性の肺癌とは組織学的に明らかに区別が できる時と容易でない場合とがある。また他 の, 例えば腹部などの遠隔器官からの転移もあ るし, 他臓器に癌が確認されても肺や肋膜に転 移していないと胸部レ線写真としては何らの所 見を示さない場合も少なくない。しかし，この 会員で少なくとも 1 回は検診に参加した 475 名 では悪性腫瘍に関する再発, 転移, 重複癌は記 録されている筈である (第 2 表)。再発，転移

第 2 表 局所再発, 転移, 第二の癌の発生 (1970 までの総数)

$\mathrm{M}$ : 転移, $\mathrm{R}$ : 局所再発, $\mathrm{P}$ : 肺癌, $(\mathrm{P})$ : 原

発加転移加不明の肺癌, $\mathrm{O}$ : 食道癌, $\mathrm{G}$ : 胃癌,

$\mathrm{I}:$ 腸癌, $\mathrm{N}$ : 惄癌, *: 胸部フィルムに病変 を示さないもの,

\begin{tabular}{|c|c|c|c|c|c|c|c|}
\hline & -40 & -50 & $|-60|$ & -70 & $|-80|$ & $|-90|$ & 計 \\
\hline-1 & & & $\left|\begin{array}{r}\mathbf{M M} \\
\mathbf{M}\end{array}\right|$ & $\mathbf{M}$ & $\mathbf{M}$ & & 6 \\
\hline-2 & & & $\mathbf{R M}$ & (P) & $\mathrm{O}$ & & 4 \\
\hline-3 & & $\mathrm{RM}$ & $\begin{array}{r}\mathrm{G}^{*} \mathrm{R} \\
\mathrm{M}\end{array}$ & $\mathrm{MM}$ & & & 7 \\
\hline-4 & & & & $M$ & $\mathrm{G}^{*}$ & & 2 \\
\hline-5 & & & (P) & $\begin{array}{l}\mathrm{RM} \\
\mathrm{MM} \\
\end{array}$ & $\mathrm{G}^{*}$ & & 6 \\
\hline-6 & & & & $\begin{array}{c}\mathrm{MM}^{\mathrm{M}} \\
(\mathrm{P}) \mathrm{G}^{*} \mathrm{I}\end{array}$ & & & 5 \\
\hline-7 & & & $\mathbf{O M}$ & & & & 2 \\
\hline-8 & & & & & & & 0 \\
\hline-9 & & & & & & $\mathrm{G}^{*}$ & 1 \\
\hline-10 & & & $\mathrm{P}$ & $(P) G^{*}$ & (P) & & 4 \\
\hline-11 & & & & P N & & & 2 \\
\hline-12 & & & & & & & 0 \\
\hline-13 & & & & $P$ & & & 1 \\
\hline-14 & & & & & 1 & & 0 \\
\hline-15 & & & & & & & 0 \\
\hline-16 & & & & & & & 0 \\
\hline-17 & & & $\mathbf{P}$ & & & & 1 \\
\hline 計 & 0 & 3 & 13 & 19 & 5 & 1 & $41 / 475$ \\
\hline
\end{tabular}

及び第二の癌（時間的関係を無視するなら重複
癌と云えよう）を合計すると41例になるが，そ の中で第二の癌は組織学的に不確定な 5 例を含 めて19例である。19:475 と云う数字は癌年令 者でも高い率であると云う印象をうける。喉頭 癌が比較的治りやすい癌であるために術後の生 存者が多いことにも原因の一部があるであろう が, 今後は胃癌の早期手術などが進むと, 子宮 癌やその他の癌と併せて素因の問題が再検討さ れるべきことになるかもしれない。私達の場合 では，早期治療を行ない得たか，あるいは可成 り進行したものでも手術や放射線治療などで延 命効果を挙げているものを合わせて, 現在の第 二の癌患者の生存者は 7 例である。後期, 特に 術後10年以上で肺癌が多いのは注意を惹く。こ の意味付けは困難であるが，他の場合よりも強 いと考えられるこの集団での慢性の気管支刺激 も一つの要因となろう。

3）炎症（以下，第 3，4表）：反覆再発性の炎 症が気管支肺系に起り易いであろうことは初め から想像に難くはない。しかし，その病変を検 查時に実際に発見する頻度は低いのが当然で,

数日〜数週間で経過してしまう炎症が，年 1 回 の検査当日にあたるといらのは全く偶然にも等 しいからである。従つて炎症のレ線所見は当然 大切ではあるが, あとに述べる炎症後遺症とし ての肺線維性変化や隣接肋膜に波及した肋膜炎 後の療着などの変化となつて認められる可能性 が高いと云えよう。

術後の気管開口部が狭くて, 呼吸困難を起す ために，患者自身がやむなく工夫したカニュー レを入れている数例のものは, 肺活量もその 1 秒率も悪いことを示すとともに，同時的な肺の 炎症, さらには無気肺と炎症を持つているもの が少なくなかつたことには注意しておきたい。 この炎症は大部分が右中葉にあつた。

3）肺の線維性変化：既に述べたように，また 表 3，4で見るように, 私達は線維性変化を表 わす像として，いくつかのものを採り上げた。 その中には在来から問題にされている異常線状 影, 網状影, 結節〜斑点影がある。私達は肺の 血管影とこれに伴ら気管支影を肺紋理と一応定 義して, それ以外のこれらと無関係に走るよう な線状影を問題にした。従つて, その代表的な 
第 3 表 年令とレ線所見 (1970)

（）：前回に比べて陰影増強

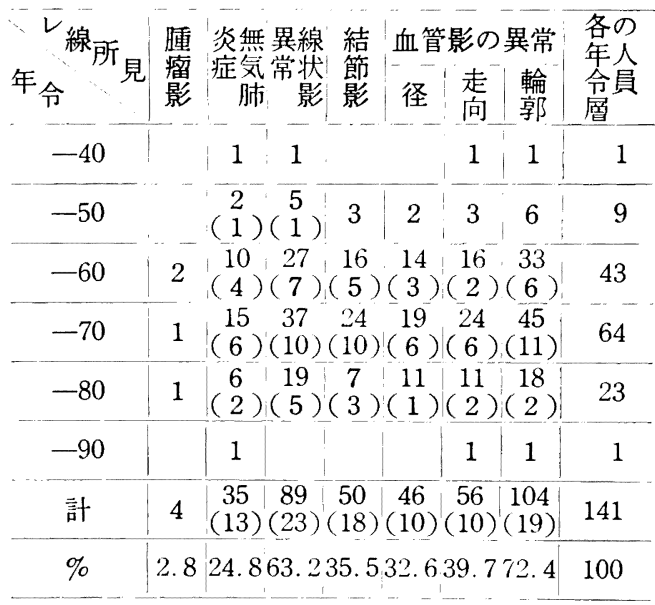

第 4 表 術後経過年数とレ線所見 (1970)

( )：前回に比べて陰影増強

\begin{tabular}{|c|c|c|c|c|c|c|c|c|}
\hline 線所 & 腫 & & & 結 & 血管 & 影の & 異常 & 各人 \\
\hline 年数 & | 瘾 & 症気 & 常状 & 節 & 径 & \begin{tabular}{|l|} 
走 \\
劣
\end{tabular} & 輪 & 域 \\
\hline-1 & 1 & 2 & $\left.\mid \begin{array}{l}8 \\
3\end{array}\right)$ & $\left(\begin{array}{c}6 \\
3\end{array}\right)$ & $\left(\begin{array}{l}4 \\
1\end{array}\right)$ & 4 & 8 & 15 \\
\hline-2 & & 2 & 5 & 2 & 2 & 5 & 7 & 10 \\
\hline-3 & & $\left(\begin{array}{l}3 \\
(1)\end{array}\right.$ & 9 & 4 & 3 & 8 & 10 & 16 \\
\hline-4 & & $\left(\begin{array}{l}4 \\
(3)\end{array}\right)$ & $\left(\begin{array}{l}5 \\
2\end{array}\right)$ & 4 & 2 & 2 & $\left(\begin{array}{l}5 \\
1\end{array}\right)$ & 9 \\
\hline-5 & 1 & $|7|$ & $\left.\mid \begin{array}{l}6 \\
1\end{array}\right)$ & 4 & 3 & 7 & 8 & 10 \\
\hline-10 & 1 & $\begin{array}{c}13 \\
(7)\end{array}$ & $\begin{array}{l}37 \\
(12)\end{array}$ & $\left(\begin{array}{c}21 \\
(10)\end{array}\right.$ & $\left(\begin{array}{l}21 \\
(6)\end{array}\right.$ & $\begin{array}{c}22 \\
(7)\end{array}$ & $\begin{array}{c}46 \\
(12)\end{array}$ & 56 \\
\hline-15 & 1 & $\left(\begin{array}{l}1 \\
1\end{array}\right)$ & $\left(\begin{array}{l}9 \\
2\end{array}\right)$ & 2 & 5 & 1 & $\left(\begin{array}{l}9 \\
2\end{array}\right)$ & 13 \\
\hline-20 & & $\left(\begin{array}{l}2 \\
1\end{array}\right)$ & $\left(\begin{array}{l}9 \\
4\end{array}\right)$ & $\begin{array}{l}6 \\
(4)\end{array}$ & $\left(\begin{array}{l}5 \\
2\end{array}\right)($ & $\left(\begin{array}{l}6 \\
(2)\end{array}\right.$ & $\left(\begin{array}{l}8 \\
3\end{array}\right)$ & 9 \\
\hline $21-$ & & & & 1 & $(1)$ & $\left.\begin{array}{l}1 \\
1\end{array}\right)$ & $\begin{array}{l}1 \\
(1)\end{array}$ & 1 \\
\hline 不 詳 & & 1 & & & & & 2 & 2 \\
\hline 計 & 4 & $\begin{array}{c}35 \\
(13)\end{array}$ & $\begin{array}{l}89 \\
(23)(\end{array}$ & \begin{tabular}{|}
50 \\
$(18)$
\end{tabular} & $\begin{array}{l}4 \overline{46} \\
(10)\end{array}$ & $\begin{array}{l}56 \\
(10)\end{array}$ & $\begin{array}{l}104 \\
(19)\end{array}$ & 141 \\
\hline$\%$ & 2.8 & 24.8 & 63.23 & 35.53 & 32.63 & 39.77 & 72.4 & 100 \\
\hline
\end{tabular}

ものの一つには Kerley のA，B，C線，特に B線があり, 板状無気肺がある。また本来は点 状影として表われるべき筈のものの連続影も線 状影として肉眼に映じるものである。結節〜点 状影には, 細い血管の正切像や交叉のために合 成されたものなどを出来るだけ除外し, 間質性 や細葉性の，しかも一過性でないようなものを
採つた。この中には炭粉などによる塵肺結節加 ら小無気肺まで種々のものが含まれる。

最も注意したいのは肺紋理，すなわち大部分 は血管影の異常であつて，これには上述のよう に項目走区別した。慢性気管支炎，間質の籍血 から間質性肺炎, 肺胞内への浸潤, 気管支周囲 及び血管周囲に起る間質の結合織の増殖, 小無 気肺，限局性気腫などの個々あるいは綜合的な 変化, さらに肺線維症と云われる程度に進んだ ものをレ線的にある程度早期から捉えるのに是 非とも必要な観察の要点であると考えている。 すなわち

a ：血管影の径の異常：末梢へ行くほと滑 らかに, 次第に細くなる筈の正常の姿から外れ て, 細くなり太くなり, しかもかなり急激に変 化する，時には閉鎖される。

$\mathrm{b}$ ：血管影の走向の不整： 線維性変化や無 気肺のための屈曲もあるし, 気腫のための伸展 もある。局所的気腫は線維性変化に関係が深 い。

c：血管影の輪郭の不規則化：正常の血管 影はたとえそれが淡くとも鮮鋭で，しかも円滑 な輪郭を示すものであるが，血管周囲に胞隔 炎, 肺胞内浸潤, 結合織の増殖などで無気状態 の組織ができると，それが血管影に附加されて 起る。

この $\mathrm{a}, \mathrm{b}, \mathrm{c}$ のどれも病変の度が低いほど 末梢の細小血管に見られ，程度が進むにつれて 次第に太い血管影に変化が及ぶのを証明する。 c が三者の中では最も多いが，異常線状影の頻 度と大体に平行関係にある。これらについて, この集団内で，年令と経過年数と関連させてし らべて見ると，もともと高令者が多く，さらに 経過年数とともに加令して行くためか, 両者の 間に差はない。しかし, 異常線状影と走向の里 常を非手術者及び手術者の術前の写真を対照と して見ると，70才以下では喉摘者の方が上迴る ことを認めた（図 1，2）。

要するに, 喉摘者の気管開口部からの直接呼 吸は, 異常な発声法の際に必要とされる努力性 呼吸とともに，気管支・肺系を種々の外来刺激 に直面させ, 炎症と婜高の機会を与えて, 肺の 線維性変化を自然の力合嫁兴上に促進してい 


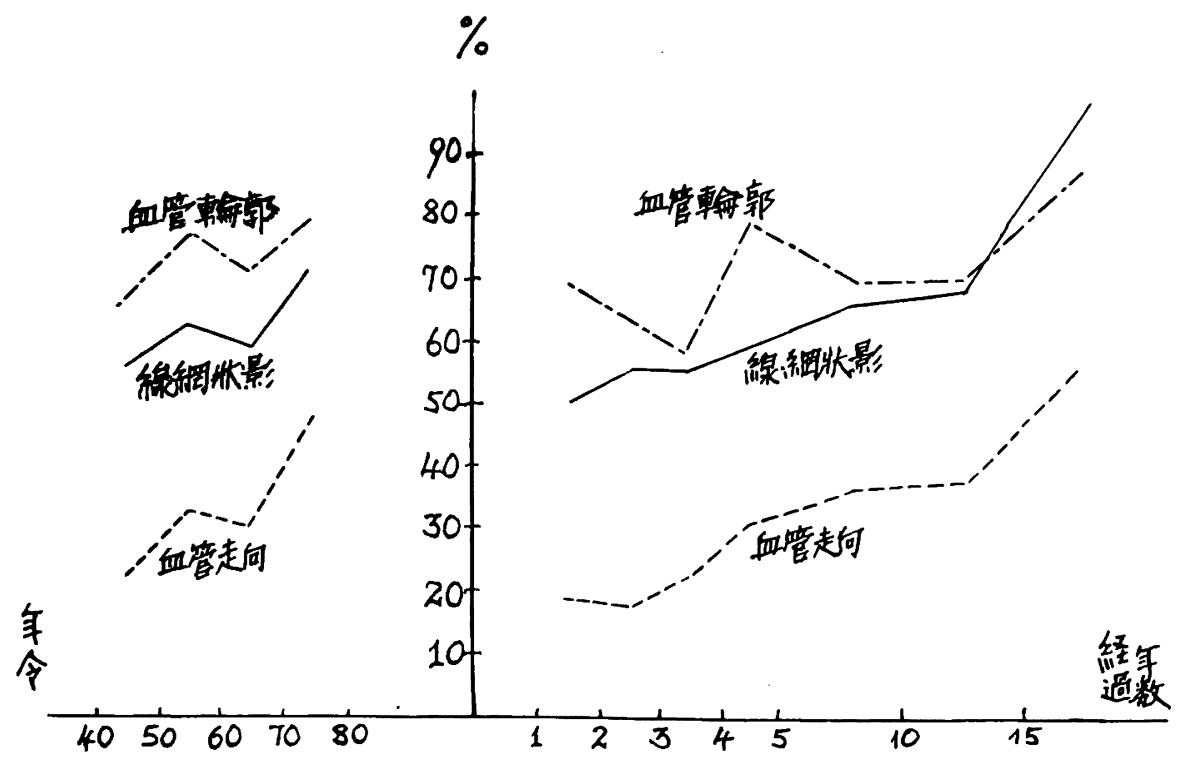

図 1 年令及び術後経過年数と異常線・網状影, 血管影の不規則走向, 輪郭不整との関係

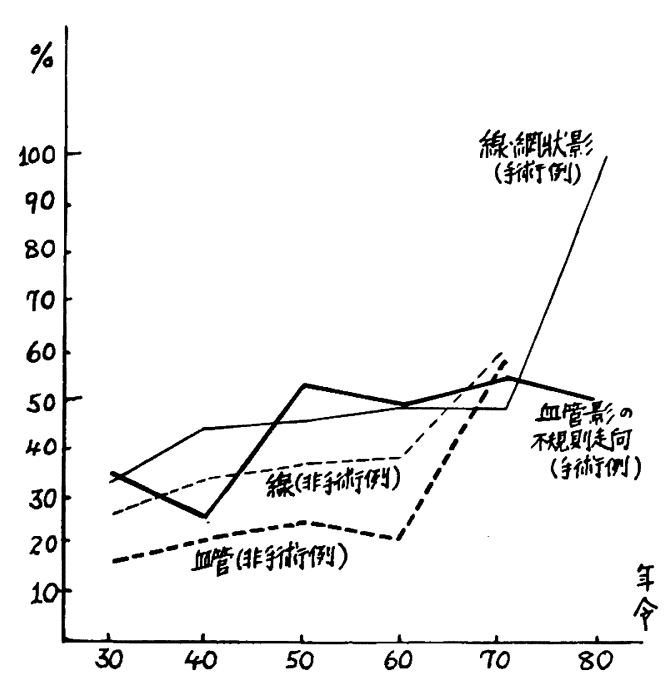

图 2 異常線網状影と血管影の不規則走向の出現 と年令との関係

ると云えよら。そしてこれらを捉えるのには血 管影の異常と線状網状影の出現に注意するのが
必要であり，それらを詳細に検討するのには拡 大撮影法が有効であり，これに気管支及び血管 造影法を併せて用いるなら尚よい判定の資料が 得られるのである。

上記の種々な場合のレ線写真については, 紙 数の都合もあるので省略するが, 末尾に記載し た参考文献の中の著者らのものに報告し発表し てあるので, 興味を持たれる方々はこれらを参 照されたい。

\section{参考献}

1) 立入弘他：喉頭癌剔出術後の気管呼吸者の肺に ついての研究——その胸部レ線所見を中心として

一。日本胸部臨床, 24, (5), 347-357, 1965.

2) H. Tachiiri, et al. : Veränderungen de Thoraxorgane bei laryngektomierten Patienten unter besonderer Berücksichtigung radiologischer Befunde. Fortsch. Röntg 107, (1), 81-89, 1967.

3) T.W. Staple, et al. : The Chest Roentgeno geram Following Supraglottic Subtotal Laryng ectomy. Am. J. Roentg., 100, (3),583-587, 1967.

4) 立入弘：喫煙と大気污染の医学—レントゲン 学的アプローチー $50-70,1970$, 金原出版 